\title{
Comparison of skin closure methods in Abdominal Surgeries: Adhesive 2 - Octylcyanoacrylate/Staples/Suture Materials.
}

\author{
${ }^{1}$ Saravanan P. S.*, ${ }^{2}$ Ravinthar A., ${ }^{3}$ Sundarprakash S. \\ ${ }^{1}$ Professor, Department of Surgery, Meenakshi Medical College \& Research Institute. Kanchipuram. No: 19, \\ Vinayagar Street, Arcot - 632 503. Vellore District. Tamilnadu. India. \\ ${ }^{2}$ Associate Professor, Department of Surgery, Meenakshi Medical College\& Research Institute. Kanchipuram. \\ No: 40, $10^{\text {th }}$ street, Kamaraj Nagar. Avadi. Chennai - 600071. India. \\ ${ }^{3}$ Assistant Professor, Department of Surgery, Meenakshi Medical College \& Research Institute. Kanchipuram.
}

\begin{abstract}
The most important and necessary step in any surgical procedure is Closure of skin. Sutures and staples are the traditional methods of wound closure, while tissue adhesives have entered clinical practice more recently.

Closure of wounds with sutures enables meticulous closure, but they may show tissue reactivity and can require removal.

Closure of wounds with staples offers the advantage of faster closure, less tissue reactivity but post-operative site pain and cost are major factors of its low acceptance.

Tissue adhesives offer the advantages of no risk of needle stick injury and no requirement to remove sutures later. Tissue adhesives have better cosmetic outcome, some brands offer adhesives even with anti-bacterial (especially against Gram +ve bacilli) and anti-fungal properties so post-operative infection rate is the least with adhesives.
\end{abstract}

\section{Aims \& Objectives}

Advantages or disadvantages of use of 2-Octyl Cyanoacrylates in comparison to sutures and Staples in closure of such wounds
a) Cost Effectiveness
b) Cosmetic outcome
c) Time consumed.
d) Post-operative infection and hematoma formation.
e) Site dehiscence.
f) Post-operative pain.

\section{Source Of Data}

\section{Materials And Methods}

This is a prospective study. Cases are taken from those admitted in department of surgery at Meenakshi Medical College Hospital and Research Institute. Kanchipuram.

Sample size: 30 Cases

Study duration: 18 months

Results:

The study groups included 30 patients who underwent wound closure by Sutures (Ethylone 3-0), staplers and 2-Octyl Cyanoacrylate. It took the 2-Octyl cyanoacrylate statistically significant less duration to perform wound closure $(\mathrm{P}<0.001)$. The appearance of the scar among the surute group was $100 \%$, 2octyl cyanoacrylate was $90 \%$ and staple groups was good in $60 \%$ of those who returned for follow up. The average cost of using 2-octyl cyanoacrylate was highest followed by staple and least in suture group statistically significant $(\mathrm{P}<0.001)$

\section{Conclusion:}

2-Octyl cyanoacrylate is effective and reliable Skin closure, yielding less post-operative pain, less complications, and good cosmetic results. Octylcyanoacrylate skin closure is faster than suturing and staple wound closure and offers several practical advantages over suture and staple repair for patients with less complication. 


\section{Source Of Data}

\section{Materials And Methods}

This is a prospective study. Cases are taken from those admitted in department of surgery at Meenakshi Medical College Hospital and Research Institute. Kanchipuram.

Sample size: 30 Cases

Study duration: 18 months

\section{Inclusion Criteria}

\section{Methods Of Collection Of Data}

All patients of both sexes who are 12 years of age or older undergoing Laparotomy and are medically lit to undergo the procedure will be included.

\section{Exclusion Criteria}

1) Patients age less than 12 years of age.

2) Patients with skin diseases in the operating area.

3) Patients suffering from Diabetes Mellitus, HIV, Immuno-compromised status.

Details will be noted in detail and tabulated. Post-operative assessment with respect to postoperative pain, hospital stay and other complication will be included as per protocol.

- Analgesics (NSAIDS like Diclofenac) given 12 hourly for 3-5 days, shifted on to oral tablets as early as possible.

- Dressing is changed once on post-operative day and every alternate day thereafter.

The following data will be recorded;

1. Details of the participants including disease characteristics

2. Details of the type of intervention (adhesive, suture or staples)

3. Details of the outcomes reported, including method of assessment and time intervals. Cosmetic appearance will be included measured on a validated scale.

Patients were observed for any complications like hematoma, seroma, wound during their stay and also assessed for post-operative pain and its severity normal life.

Patients were discharged once free of complications and once they resumed their activity of daily

At discharge they were advised to come for review suture or staples removal 7th day in case skin closure is done with sutures or staples and just to see the scar case adhesives and follow up on day 15, Day 30 and 4 months of surgery was done.Patients are instructed to avoid heavy work for a period of 3-4 weeks.

\section{Observation And Results}

A TOTAL OF 30 PATIENTS WERE INCLUDED IN THE STUDY 10 IN GROUP A I.E... SUTURES, 10 IN Group B I.E... STAPLES AND 10 IN GROUP C I.E...20CTYL CYANOACRYLATE

\section{Distribution Of Diagnosis:}

\begin{tabular}{|l|l|l|l|l|}
\hline \multicolumn{1}{|c|}{ Diagnosis } & \multicolumn{1}{|c|}{ Staples } & \multicolumn{1}{|c|}{$\begin{array}{c}\text { 2 Octyl } \\
\text { Cyanoacrylate }\end{array}$} & $\begin{array}{c}\text { Ethylone } \\
\mathbf{3 - 0}\end{array}$ & \multicolumn{1}{|c|}{ Total } \\
\hline Acute Intestinal Obstruction & $2(20 \%)$ & $0(0 \%)$ & $0(0 \%)$ & $2(6.7 \%)$ \\
\hline Appendicitis & $2(20 \%)$ & $3(30 \%)$ & $1(10 \%)$ & $6(20 \%)$ \\
\hline Cholecystitis & $1(10 \%)$ & $1(10 \%)$ & $1(10 \%)$ & $3(10 \%)$ \\
\hline Gastric Outlet Obstruction & $0(0 \%)$ & $1(10 \%)$ & $1(10 \%)$ & $2(6.7 \%)$ \\
\hline Hydratid Cyst Liver & $1(10 \%)$ & $0(0 \%)$ & $1(10 \%)$ & $2(6.7 \%)$ \\
\hline Rectal Prolapse & $1(10 \%)$ & $1(10 \%)$ & $0(0 \%)$ & $2(6.7 \%)$ \\
\hline Inguinal hernia & $2(20 \%)$ & $4(40 \%)$ & $6(60 \%)$ & $12(40 \%)$ \\
\hline Splenic Trauma & $1(10 \%)$ & $0(0 \%)$ & $0(0 \%)$ & $1(3.3 \%)$ \\
\hline Total & $10(100 \%)$ & $10(100 \%)$ & $10(100 \%)$ & $30(100 \%)$ \\
\hline
\end{tabular}

In 30 patients included in the study patients suffering from inguinal hernia are in majority $12(40 \%)$. 
Type Of Incisions In Patients Studied

\begin{tabular}{|l|l|l|l|l|}
\hline \multicolumn{1}{|c|}{ Type incision } & \multicolumn{1}{|c|}{ Staples } & \multicolumn{1}{|c|}{$\begin{array}{r}\text { Ectyl } \\
\text { Cyanoacrylate }\end{array}$} & $\begin{array}{r}\text { Thylone 3- } \\
\mathbf{0}\end{array}$ & \multicolumn{1}{|c|}{ Total } \\
\hline Inguinal & $2(20 \%)$ & $4(40 \%)$ & $6(60 \%)$ & $12(40 \%)$ \\
\hline Mac Berneys & $2(20 \%)$ & $3(30 \%)$ & $1(10 \%)$ & $6(20 \%)$ \\
\hline Midline & $5(50 \%)$ & $2(20 \%)$ & $2(20 \%)$ & $9(30 \%)$ \\
\hline Rt Subcostal & $1(10 \%)$ & $1(10 \%)$ & $1(10 \%)$ & $3(10 \%)$ \\
\hline Total & $10(100 \%)$ & $10(100 \%)$ & $10(100 \%)$ & $30(100 \%)$ \\
\hline
\end{tabular}

In 30 patients included in the study patient's inguinal incision is closed in $12(40 \%)$ patients.

\section{Length Of Incisions In Patients Studied:}

\begin{tabular}{|l|l|l|l|l|}
\hline Length & Staples & $\begin{array}{l}\mathbf{2} \text { Octyl } \\
\text { Cyanoacrylate }\end{array}$ & $\begin{array}{l}\text { Ethylone 3- } \\
\mathbf{0}\end{array}$ & Total \\
\hline $1-5$ & $1(10 \%)$ & $1(10 \%)$ & $1(10 \%)$ & $3(10 \%)$ \\
\hline $6-10$ & $4(40 \%)$ & $8(80 \%)$ & $7(70 \%)$ & $19(63.3 \%)$ \\
\hline$>10$ & $5(50 \%)$ & $1(10 \%)$ & $2(20 \%)$ & $8(26.7 \%)$ \\
\hline Total & $10(100 \%)$ & $10(100 \%)$ & $10(100 \%)$ & $30(100 \%)$ \\
\hline Mean \pm SD & $10.50 \pm 3.69$ & $8.10 \pm 1.91$ & $8.10 \pm 2.47$ & $8.90 \pm 2.93$ \\
\hline
\end{tabular}

In 30 patients included in the study the surgical incisions ranged from 5 to $16 \mathrm{cms}$ with majority of incisions measuring between $6-10 \mathrm{cms}$ in $19(63.3 \%)$ patients.

Time Taken For Closure In Seconds:

\begin{tabular}{|l|l|l|l|l|}
\hline $\begin{array}{c}\text { Time taken } \\
\text { for closure } \\
\text { (seconds) }\end{array}$ & \multicolumn{1}{|c|}{ Staples } & \multicolumn{1}{|c|}{$\begin{array}{c}\text { 2 Octyl } \\
\text { Cyanoacrylate }\end{array}$} & Ethylone 3-0 & Total \\
\hline$<24$ & $0(0 \%)$ & $10(100 \%)$ & $0(0 \%)$ & $10(33.3 \%)$ \\
\hline $25-36$ & $4(40 \%)$ & $0(0 \%)$ & $0(0 \%)$ & $4(13.3 \%)$ \\
\hline $37-48$ & $2(20 \%)$ & $0(0 \%)$ & $0(0 \%)$ & $2(6.7 \%)$ \\
\hline $48-72$ & $2(20 \%)$ & $0(0 \%)$ & $4(40 \%)$ & $6(20 \%)$ \\
\hline$>72$ & $2(20 \%)$ & $0(0 \%)$ & $6(60 \%)$ & $8(26.7 \%)$ \\
\hline Total & $10(100 \%)$ & $10(100 \%)$ & $10(100 \%)$ & $30(100 \%)$ \\
\hline Mean \pm SD & $56.70 \pm 38.58$ & $13.00 \pm 4.55$ & $82.60 \pm 25.23$ & $50.77 \pm 38.98$ \\
\hline
\end{tabular}

In 30 patients included in the study the time taken for closure of operative wound ranged from $8-128$ secs. With mean time being statistically significantly less in group closed by 2 -octyl cyanoacrylate $(\mathrm{P}<0.001)$.

\section{Cost Of Materials Used In Rupees:}

\begin{tabular}{|l|l|l|l|l|}
\hline Cost of Material used (Rs) & \multicolumn{1}{|c|}{ Staples } & $\begin{array}{c}\text { 2 Octyl } \\
\text { Cyanoacrylate }\end{array}$ & $\begin{array}{c}\text { Ethylone } \\
\mathbf{3 - 0}\end{array}$ & \multicolumn{1}{|c|}{ Total } \\
\hline$<200$ & $3(30 \%)$ & $0(0 \%)$ & $10(100 \%)$ & $13(43.3 \%)$ \\
\hline $201-300$ & $4(40 \%)$ & $0(0 \%)$ & $0(0 \%)$ & $4(13.3 \%)$ \\
\hline $301-400$ & $1(10 \%)$ & $0(0 \%)$ & $0(0 \%)$ & $1(3.3 \%)$ \\
\hline$>400$ & $2(20 \%)$ & $10(100 \%)$ & $0(0 \%)$ & $12(40 \%)$ \\
\hline Total & $10(100 \%)$ & $10(100 \%)$ & $10(100 \%)$ & $30(100 \%)$ \\
\hline \multicolumn{1}{|l|}{$\mathrm{P}=<0.001^{* *}$} & & & & \\
\hline
\end{tabular}

In 30 patients included in the study the cost of material for closure of operative wound ranged from 110-1000rs. Being statistically significantly less in group closed by Ethylone 3-0 $(\mathrm{P}<0.001)$. 
Cosmetic Outcome (Using Hollanders Wound Evaluation Scale):

\begin{tabular}{|l|l|l|l|l|}
\hline $\begin{array}{c}\text { Cosmetic } \\
\text { outcome }\end{array}$ & \multicolumn{1}{|c|}{ Staples } & \multicolumn{1}{|c|}{$\begin{array}{c}\text { 2 Octyl } \\
\text { Cyanoacrylate }\end{array}$} & Ethylone 3-0 & \multicolumn{1}{|c|}{ Total } \\
\hline 4 & $2(20 \%)$ & $0(0 \%)$ & $0(0 \%)$ & $2(6.7 \%)$ \\
\hline 5 & $2(20 \%)$ & $1(10 \%)$ & $0(0 \%)$ & $3(10 \%)$ \\
\hline 6 & $6(60 \%)$ & $9(90 \%)$ & $10(100 \%)$ & $25(83.3 \%)$ \\
\hline Total & $10(100 \%)$ & $10(100 \%)$ & $10(100 \%)$ & $30(100 \%)$ \\
\hline
\end{tabular}

In 30 patients included in the study the cosmetic outcome using Hollander wound evaluation on 120day operative wound was found to be optimal in 100\% patients in group closed by Ethylone 3-0 closely followed by $90 \%$ in 2-octyl cyanoacrylate and least $60 \%$ in group closed by staples.

\section{Summary}

30 PATIENTS WERE INCLUDED IN THE STUDY 10 IN GROUP A I.E... SUTURES 10 IN GROUP B I.E.. STAPLES AND 10 IN GROUP C I.E...2-OCTYLCYANOACRYLATE.

Majority were operated for inguinal Hernia $12(40 \%)$

The length of surgical wounds ranged from 5 to $16 \mathrm{cms}$ with incisions measuring between $6-10 \mathrm{cms}$ in $19(63.3 \%)$ patients.

The time taken for closure of operative wound ranged from $8-128$ secs. With mean time being statistically significantly less in group closed by 2 -octyl cyanoacrylate $(\mathrm{P}<0.001)$.

The cost of material for closure of operative wound ranged from 110- 1000/-. Being statistically significantly less in group closed by Ethylone 3-0 $\quad(\mathrm{P}<0.001)$.

The cosmetic outcome using Hollander wound evaluation on 120day operative wound was found to be optimal in $100 \%$ patients in group closed by Ethylone 3-0 closely followed by $90 \%$ in 2-octyl cyanoacrylate and least $60 \%$ in group closed by staples.

The pain scoring using visual analogue scale was found to be highest in patients in group closed by staples closely followed by group closed by Ethylone $\quad 3-0$ and least in group closed by 2-octyl cyanoacrylate.

Only 1 patient from group 2-octylcyanoacrylate developed postoperative collection (seroma)which was aspirated and resolved using a needle and a syringe.

Only 1 patient from group 2-octylcyanoacrylate developed wound dehiscence following seroma formation the wound gaping persisted even on last follow-up. i.e.. 120days postoperatively.

\section{Discussion}

Wound closure is as important as any other action performed by the surgeon. The practical difficulties involved in wound healing like involvement of more than one type of tissue, variable wound strength during the process of healing, exposure of the biomaterials to body fluids and a variety of wounds, each with its own healing problems, call for different types of wound closure materials ${ }^{[1,2,3]}$.

Multiple studies have shown equivalence of octyl cyanoacrylate to 5-0 skin sutures in esthetic facial surgery and repair of traumatic facial wounds ${ }^{[4,5]}$.

Wound closure biomaterials are divided into three major categories: suture materials, staples and tissue adhesives. Suturing has been the most widely used method for wound closure because of high reliability of suture materials. However, alternative techniques have long been sought, since suturing technique requires skill and experience, a relatively longer time and the need for its removal. Due to these reasons, surgeons are increasingly using tissue adhesives over sutures for wound closure ${ }^{[6,7]}$.

Post-operative site infection is a common problem and has a significant impact on patients and healthcare systems. More than $70 \%$ of surgical procedures are now performed on a outpatient basis, which poses major problems for surveillance of surgical site infections(Emori 1993) ${ }^{[8]}$. One may anticipate that a tissue adhesive offers a barrier to micro-organisms at the site of the healing incision and may therefore have some success towards reducing wound infection. However, the studies identified for this review did not demonstrate any significant difference in the proportion of wounds with infections when incisions were closed with tissue adhesives or other conventional techniques. Typically an infection was considered present if any of the following were observed: redness, swelling, purulent discharge, pain, increased skin temperature, fever or other systemic signs of infection.

Surgeon satisfaction typically sought ratings for wound cosmesis or ease of use for the technique. Certainly there is no risk of needle stick injury to the surgeon whilst using adhesive rather than sutures and this 
may be a factor though none of the studies in this review considered this. Time to closure as an outcome measure was included in the review post hoc as the review authors believe this to be a contributory factor towards both cost-effectiveness and satisfaction. Time taken is an attractive aspect for surgeons yet it should be noted that although there may be a significant difference in time taken for closure the overall time taken was still relatively small in both groups with even the longest closure times rarely exceeding 2 minutes. In clinical practice the reduction of wound closure time by using the quickest method may be insufficient to increase the number of operations in a given operating room schedule. However a faster wound closure technique may increase surgeon satisfaction and may also be attractive to patients when surgery is undertaken using only local anesthetic. Alternatively, patients may be happy with a lengthier closure time for a technique which achieves better outcomes. Generally, tissue adhesives cost more than alternatives. An ampoule of tissue adhesive may be three times or more the cost of a suture required to close the same incision length. However, a dressing is not required over the tissue adhesive as is the usual with alternatives. Also, when taking into the account the overall cost of the surgical procedure then this small difference may be of less significance.

In summary there is evidence to show that dehiscence rates may be higher in wounds closed with tissue adhesives when compared with sutures. There is also some evidence that the time taken to close the wound closure may be longer when using tissue adhesives than sutures, tapes or staples. Despite surgeons and patients being significantly more satisfied with the alternatives to adhesives in one analysis this is not supported in other analyses.

\section{Conclusion}

2-Octylcyanoacrylate is effective and reliable Skin closure,

- $\quad$ Yielding less post-operative pain,

- $\quad$ Less complications, and

- $\quad$ Good cosmetic results

- Octylcyanoacrylate skin closure is faster than suturing and staple wound

closure

Offers several practical advantages over suture and staple repair for patients with less complication.

\section{Refereneces:}

[1]. Key SJ, Thomas DW, Shepherd JP. The management of soft tissue facial wounds. Br J Oral Maxillofac Surg. 1995;33:76-85.

[2]. Chu CC, von Fraunhofer A, Greisler HP. Florida, USA: Mosby publications; 1997. Wound closure biomaterials and devices; pp. 13. (317).

[3]. Hollander JE, Singer A, Valentine S, Henry MC. Laceration management. Ann Emerg Med. 1999;34:356-67.

[4]. Toriumi DM, O’Grady K, Bagal AA. Use of octyl-2-cyanoacrylate for skin closure in facial plastic surgery. Plast Reconstr Surg. 1998;102:2209-19.

[5]. Choi BH, Kim BY, Huh JY, Lee SH, Zhu SJ, Jung JH, et al. Cyanoacrylate adhesive for closing sinus membrane. J Craniomaxillofac Surg, 2006;34:505-9.

[6]. Reece TB, Maxey TS, Kron IL. A prospectus on tissue adhesives. Am J Surg. 2001;182:40s-4s.

[7]. Morikawa T. Tissue sealing. Am J Surg. 2001;182:29s-35s

[8]. Emori TG, Gaynes RP. An overview of nosocomial infections, including the role of the microbiological laboratory. Clinical Microbiology 1993;6:428-42. 